logos_i_ethos_2016_(43)_numer_specjalny_2, s. 165-179

DOI: http://dx.doi.org/10.15633/lie.1967

\author{
Прот. Георгий Ореханов
}

\title{
Религиозный кризис (Лев Толстой и Петр Чаадаев)
}

Как указывает русский философ И. А. Ильин, кризисные ситуации - это не автоматически катастрофа, как мы часто склонны думать. Это ситуации, когда опыт Прот. Георгий Ореханов - профессор кафедры история Русской Православной Церкви, проректор Православного Свято-Тихоновского Гуманитарного Университета по международной работе. человека, группы людей или социума претерпевает решающее испытание. В кризисных ситуациях выступают скрытые силы, некие резервы, использование или неиспользование которых приводит либо к обновлению, либо к смерти, катастрофе. Другими словами, кризис культуры - это всегда некоторая задача, которая должна быть разрешена и неразрешение которой чревато самыми тяжелыми последствиями ${ }^{1}$.

Можно определить религиозный кризис как ситуацию, когда «внутренняя когеренция» человека, то есть, во-первых, его «индивидуальная догматика», во-вторых, его способность решать жизненные задачи, наконец, в-третьих, использование им религиозного языка, конкретных значений религиозных понятий претерпевают значительную трансформацию.

Безусловно, религиозный кризис чаще всего вызван субъективными обстоятельствами жизни человека. Это происходит, например, когда мы говорим о религиозном обращении или, наоборот, о потере религиозного чувства, потере религиозной веры. Но для конкретного поколения кризис часто определяется 
определенными объективными историко-культурными факторами, например, значительными социальными сдвигами или потрясениями. Другими словами, религиозный кризис поколения тесно связан с индивидуальными кризисами: не только для отдельных людей, но для целого поколения возникает необходимость конструирования новой системы ценностей, в которой найдется место вере. И здесь нужно сделать одно очень важное замечание. Кризис религии далеко не всегда заключается в постепенном затухании религиозности. Он состоит в том, что на каждом определенном историческом этапе религиозность есть такой продукт внешних факторов (например, секуляризации), в результате которого элементы религиозного, так, как они понимались раныше, теперь соединены с элементами совершенно другой природы. Именно поэтому возникает необходимость более точно разобраться с тем, что же такое «религия».

Другими словами, религиозный кризис всегда связан с переосмыслением старых концептов и актуализацией новых. Человек описывает свой собственный религиозный опыт нетрадиционным образом и может при этом использовать такие понятия, которые, с нашей точки зрения, именно к религии отношения не имеют, однако для самого человека являются вполне адекватным представлением его внутреннего мира, его «когеренции».

\section{1. Функциональный характер веры Л. Толстого}

Л. Толстого, как и многих других представителей его адогматического поколения, очень мало интересовал вопрос о субстанциях, о метафизических основаниях веры. Но вопрос, какую роль в жизни человека религия призвана выполнять, был для него очень принципиальным, главным. А его религиозный язык, как мы вскоре увидим, имел характерные особенности. Добавим при этом, что Лев Толстой - очень рефлексирующий автор, он сознательно стремится выразить свои переживания и жизненные основания с помощью точных понятий и именно поэтому он так долго вел свой дневник, 
о котором мы подробнее скажем ниже. Я думаю, что Л. Толстой один из самых реблексирующих авторов ХІХ века.

В дневнике Л. Толстого и его записных книжках содержится огромное количество материала, который может ярко проиллюстрировать сказанное выше. Я приведу несколько очень важных примеров.

2 июня 1878 г., то есть на самом пике своих религиозных исканий, Л. Толстой заносит в записную книжку следующую мысль: «С Богом нельзя иметь дело, вмешивая посредника и зрителя, только с глаза на глаз начинаются настоящие отношения; только когда никто другой не знает и не слышит, Бог слышит тебя» ${ }^{2}$.

Далее в этой книжке следует большой отрывок, который сам Толстой озаглавил так: «Не доказательство, но объяснение форм моей веры». Я думаю, всем понятно, сколь интересны для анализа записи подобного рода, в которых рефлексивный дар автора проявился очень глубоко.

«Формы верь» - именно то, что нас будет интересовать более всего при изучении понятия «религиозный кризис». Я не буду приводить целиком последовавшую за этим заголовком запись, обращаю только внимание на один абзац (под номером 1), в котором Л. Толстой формулирует пять «безответных вопросов», в которых проявляется «невозможность знания», но на которые может ответить религия: «а) Зачем я живу? b) Какая причина моему и всякому существованию? с) Какая цель моего и всякого существования? d) Что значит и зачем то раздвоение - добра и зла, которые я чувствую в себе? е) Как мне надо жить? Что такое смерть? Самое же общее выражение этих вопросов и полное есть: как мне спастись? Я чувствую, что погибаю - живу и умираю, люблю жить и боюсь смерти, - как мне спастись?». Мы не будем разбираться сейчас, в каком смысле Л. Толстой употребляет здесь слово

2 Л. Н. Толстой, Дневники и записные книжки 1858-1880, в: Л. Н. Толстой, Полное собрание сочинений в 90 томах, т. 48, Москва 1952, с. 187.

3 Л. Н. Толстой, Дневники и записные книжки 1858-1880, op. cit., с. 187. 
«спасение», но видим, что вопросы сформулированы предельно «функционально».

И это не случайно. Функизональность, то есть направленность не на «догматику» и метафизику, а на выявление способа, которым религия помогает человеку жить, работать и творить, является очень характерной особенностью построений Л. Толстого. Можно сказать, что первый и последний вопросы - зачем я живу? как мне надо жить? - находятся в центре религиозно-философских построений Л. Толстого.

Я хотел бы привести еще два ярких примера подобной рефлексии «функциональности религии» из тех же записных книжек Л. Толстого, которые очень важны для понимания общего смысла его религиозной концепции.

Первый пример - запись из Записной книжки № 10, сделанная, очевидно, летом 1880 года. Здесь, анализируя Нагорную проповедь (Мф 5-7 гл.), Л. Толстой отмечает, что в заповедях блаженства отсутствует какая-либо метафоричность, а также «неточности», «преувеличения», «переносный смысл»: «Все ясно, просто - что должно делать, $\kappa a \kappa »{ }^{4}$. Именно функциональная ясность, то есть ясность, с точки зрения Л. Толстого, иели (что?) и способа (как?) является залогом истинности религии. Кроме того, для Толстого важно, что Нагорная проповедь предписывает определенный способ действия, то есть возможность изменения - себя самого и окружающего мира. С его точки зрения, покаяние есть не столько мистический процесс, сколько изменение личности, ее трансформация в процессе исполнения заповедей. Далее Л. Толстой подчеркивает парадоксальность, с его точки зрения, восприятия Евангелия: «То, что можно делать, что понятно, ясно и предписано», историческая Церковь якобы всегда воспринимала только метафорически; наоборот, «то, что непонятно, глупо, чего нельзя даже делать», то она понимала прямо 5 . Отметим сразу же, что именно Нагорная проповедь станет тем базовым текстом, на

4 Л. Н. Толстой, Дневники и записнье книжки 1858-1880, op. cit., с. 324.

5 Л. Н. Толстой, Дневники и записные книжки 1858-1880, op. cit., с. 324. 
основании которого писатель в дальнейшем построит свою проповедь. С его точки зрения, функциональная ясность Нагорной проповеди (то, что просто, естественно и исполнимо) должна быть противопоставлена тем «неподлинным» отрывкам Евангелия, которые, наоборот, проникнуты метафоричностью, неясностью, неточностями. К этим отрывкам Л. Толстой относит все евангельские чудеса и все то, что проникнуто расплывчатым, с его точки зрения, мистицизмом, например, учение Христа о Евхаристии (Ин, 6 гл.).

Сравним сказанное выше еще с одной яркой мыслью из записных книжек. После сказанного «функциональный» характер мысли Л. Толстого становится еще более очевидным: «Почему этические законы - проявления божества? Потому что знать, что хорошо и что дурно, что надо любить, однозначуще = знанию того, зачем я есть, куда я иду, к чему стремлюсь» ${ }^{6}$.

Таким образом, граф Лев Толстой подходит к сути своего собственного религиозного кризиса, последствия которого он стремится распространить на всех людей. По Толстому (заметим, что здесь он находился вполне в русле европейской просвещенческой традиции), представление о религии заложено в человеческом естестве, в сердце и душе человека, оно просто и ясно и не требует никаких мистических усилий или переживаний, не укладывающихся в опыт человека.

\section{2. Л. Н. Толстой и П. Я. Чаадаев: попытка типологического сопоставления}

\section{1. Исторические связи и взаимные отзывы}

Л. Н. Толстой - троюродный племянник П. Я. Чаадаева. Писатель не знал об этом родстве, а идеи Чаадаева стали известны ему в конце жизни (в 1906 г.) через В. В. Стасова. В Яснополянской библиотеке сохранились две книги П. Я. Чаадаева: Апология сумасшедшего (Казань, 1906) и Философические письма (Казань, 1906). 
Вот отзыв из письма В. В. Стасову от 24 декабря 1905 г., который содержит в себе одну из двух известных исследователям ссылок Л. Толстого на произведения П. Я. Чаадаева: «Письма Чаадаева очень интересны, и место, которое вы выписали, мне очень посердцу. Он смотрел так правильно на греческое искусство, потому что был религиозный человек» ${ }^{7}$; здесь Л.Н. Толстой имеет в виду отрывок из седьмого философического письма.

Что знал о Л. Н. Толстом П. Я. Чаадаев? Историкам известен только один отзыв П. Я. Чаадаева, незадолго до смерти, на рассказ Севастополь в мае (изданный в «Современнике» в 1855 г., № 9): «Вот это добротный патриотизм, из тех, что действительно делают честь стране, а не загоняют ее дальше в тупик, в котором она оказалась» ${ }^{8}$.

Таким образом, мы видим, что поиск исторических связей между двумя авторами серьезных успехов принести не может, поэтому нашу работу следует перенести в типологическую сферу.

\section{2. Типологические связи}

Здесь нас также ожидает большая исследовательская проблема, связанная с тем, что работа по реконструкции религиозных взглядов П. Я. Чаадаева, по исследованию их генезиса и эволюции, только начинается.

\subsection{1. Духовный переворот}

Оба автора пережили духовный переворот. Если о перевороте Л. Н. Толстого данных у нас достаточно, то о Чаадаеве этого сказать нельзя. Современный исследователь подчеркивает:

7 Л. Н. Толстой, Письма, 1905 (июль - декабрь) - 1906, в: Л. Н. Толстой, Полное собрание сочинений в 90 томах, т. 76, Москва 1956, с. 68.

8 Письмо П. Я. Чаадаева к А. Я. Булгакову, сентябрь 1855 г. (П. Я. Чаадаев, Письма, в: П. Я. Чаадаев, Полное собрание сочинений и избранные письма, т. 2, Москва 1991, с. 275). 
Будучи в молодости близким к декабристам сторонником идей Просвещения и деистом, он пережил (по всей видимости, именно во время заграничного путешествия) религиозное обращение. Некоторые моменты Филособических писем могут интерпретироваться как косвенные указания на то, что ряд философски значительных интуиций был почерпнут Чаадаевым из особого рода экстатического (мистического, трансперсонального) опыта9.

Тем не менее, кое-что в истории переворота П. Чаадаева становится более понятным, если ориентироваться на очень специфический источник - заметки на полях религиозных произведений, имевшихся в библиотеке Чаадаева. Анализируя их, другой современный исследователь, Б. Н. Тарасов делает следующие выводы:

a) В конце 1810-х - начале 1820-х годов П. Я. Чаадаев переживает духовный кризис, который заканчивается обращением к христианству. Для этих поисков характерны восхищение перед Божием величием и Его совершенством, чувство неудовлетворенности собой, понимание ограниченности человеческой природы.

б) Для религиозных построений П. Чаадаева характерны колебания, поиск понимания различных богословских подходов и категорий. Вот несколько ярких примеров указанных колебаний (пометки на страницах сочинений Ламенне, Сенеки, Гердера, Канта): «спасение? как?... когда, когда оно... Заслуга? Как оно происходит, как зарождается?..»; «А Вы, порождения ехидны, воскреснете ли Вы»; «этот человек все время твердит нам о воскресении, но так и не говорит, как он его понимает»; «Дух Бога? Вдохновение? Благодать? Дети Божии? Пророчество? Сверхестественное? Божественное? Духовное? Ум? Чудеса? Дары Божии? Глас Бога? Святой Дух?»; «христианство, Христос, православие» ${ }^{10}$.

В целом остается справедливым вывод, сделанный прот. Г. Флоровским более 70 лет назад: ства (рукопись).

9 К. М. Антонов, П. Я. Чаадаев и творческая программа религиозного западниче-

10 Б. Н. Тарасов, Непрочитанный Чаадаев, неуслышанный Достоевский (христианская мысль и современное сознание), Москва 1999, с. 18, 23-25, 29. 
Образ Чаадаева до сих пор остается неясным. И самое неясное в нем, это его религиозность. В своих дружеских письмах он был, во всяком случае, достаточно откровенен. Но даже здесь он остается только блестящим совопросником, остроумным и острословным. У этого апологета Римской теократии в мировоззрении всего меньше именно церковности. Он остается мечтателемнелюдимом, каких много было именно в Александровское время, среди масонов и пиетистов. Он идеолог, не церковник. Отсюда какая-то странная прозрачность его историософических схем. Само христианство ссыхается у него в новую идею... ${ }^{11}$.

\subsection{2. Религиозный фокус философских построений}

Этот аспект философского творчества П. Я. Чаадаева неоднократно подчеркивался исследователями. Философ стремится создать рациональный синтез, сделать религиозное учение "реальным», сочетаемым с «доктринами дня», использовать «рациональную манеру», данные и достижения естественных наук: христианство, с его точки зрения - синтез веры и науки, культуры, истории, философии и самой жизни, а прогресс основан на чисто христианской идее бесконечности. С точки зрения П. Я. Чаадаева, христианство обладает способностью «всегда согласовываться с потребностями своей эпохи», сохранять «бережно и нерушимо основное своего учения» и в то же время «бесконечно» меняться «в своей внешности» 12 . Кроме того, «раз христианство есть Слово и свет по преимуществу, оно естественно вызывает слово и распространяет возможно больший свет на все объекты интеллектуального воззрения человека» ${ }^{13}$.

11 Г. Флоровский, Пути русского богословия, http://www.vehi.net/florovsky/puti/06. html.

12 Б. Н. Тарасов, Непрочитанный Чаадаев, неусльщианный Достоевский, ор. cit., c. 35 .

13 Письмо П. Я. Чаадаева к С. С. Мещерской, 27.05.1839 (П. Я. Чаадаев, Письма, op. cit., c. 134). 


\section{3. Особенности религиозных взглядов П. Я. Чаадаева}

\section{1. Бог, вера, Предание, догматический аспект. Воскресение. Таинства}

Как указывает прот. Г. Флоровский, религиозные взгляды П. Я. Чаадаева сложились под совершенно определенным влиянием: «Его мировоззрение сложилось всего более под влиянием французского “традиционализма”, под влиянием Бональда и Балланша, отчасти де-Местра, - и личные связи соединяют Чаадаева именно с неокатолическими салонами Парижа (Сиркур, барон Экштейн, в этих же кругах вращается в те годы А. И. Тургенев)» ${ }^{14}$.

В Философических письмах очень определенно выражена идея Откровения и Промысла: «История человеческого рода не имеет смысла, если не возводить ее к первым дням мира и к сотворению человека» ${ }^{15}$; события книги Бытия «совершенно принадлежат истории», без них немыслимо шествие человеческого ума, не имеет смысла «всякий подвиг искупления», а «философия истории вовсе невозможна»; «без падения человека нет ни философии, на даже логики; все тьма и бессмыслица» ${ }^{16}$.

С точки зрения П. Я. Чаадаева, Предания - это не «идолопоклонство букве», все христианство не «замкнуто в священной книге», оно «живет в беспредельных областях духа, оно содержится в неизреченном таинстве Евхаристии, на непреходящем памятнике креста оно начертало свои мощные глаголы».

Идея воскресения у Чаадаева не играет сколько-нибудь значительной роли (видимо, поэтому и можно говорить об определенной упрощенности, даже бедности его построений), однако некоторые его высказывания в этом отношении можно понимать как близкие

14 Г. Флоровский, Пути русского богословия, ор. cit.

15 Письмо П. Я. Чаадаева к С. С. Мещерской, 27.05.1839, op. cit., с. 136.

16 Письмо П. Я. Чаадаева к И. Д. Якушкину, 1838 (П. Я. Чаадаев, Письма, ор. cit., c. 127). 
к христианским: «Христианское бессмертие это жизнь без смерти, совсем не так, как думают, жизнь после смерти». Очень характерно намерение П. Я. Чаадаева написать опровержение на известную книгу о жизни Христа Д.-Ф. Штрауса. По этому поводу интересна ремарка племянника философа, М. И. Жихарева: «Во время появления и громкой знаменитости всем известной книги Штрауса весьма образованные и очень неглупые люди различных верований и убеждений говорили, что в России только один Чаадаев в состоянии написать на нее опровержение» ${ }^{17}$.

Очень характерны взгляды П. Я. Чаадаева на церковные таинства, связанные с различением «внешней обрядности» и «верований высшего порядка», которые, впрочем, не отрицают «народных верований», но только их укрепляют. Такое представление о таинствах восходит, в свою очередь, к пониманию Чаадаевым характера Промысла: «весь распорядок духовного мира есть следствие удивительного сочетания первоначальных понятий, брошенных Самим Богом в нашу душу, с воздействием нашего разума на эти идеи», «сохранение этих основ, их передача из века в век, от поколения к поколению, определяется обычными законами [...] есть, конечно, некоторые видимые признаки, по которым можно распознать среди всех святынь, рассеянных по земле, ту, в которой, как в святом ковчеге, содержится непреложный закон истины» ${ }^{18}$.

Такой Святыней является таинство Евхаристии. Главная вина Реформации, с точки зрения П. Я. Чаадаева, заключается в расколе западного мира, в проповеди обособленности, в разрушении единства и всеобщности, в которых «заключается вся божественная идея и вся сила христианства» и их видимых знаков, из которых главным является Евхаристия:

17 Указатель имен, в: П. Я. Чаадаев, Полное собрание сочинений и избранные письма, т. 2, op. cit., с. 637-638.

18 П. Я. Чаадаев, Философические письма, в: П. Я. Чаадаев, Полное собрание сочинений и избранные письма, т. 1, Москва 1991, с. 354. 
Одна лишь видимая, осязаемая, изваянная неизменность истины может сохранить царство духа на земле. Господство мысли обретает непрерывность и длительность, лишь осуществляясь в данных формах человеческой природы ${ }^{19}$.

Таинство Причастия, «чудесное изобретение христианского разума», которое «как бы облекает души плотью для лучшего их соединения, если перестают требовать видимого единения, если довольствуются внутренним единством убеждений без внешнего воплощения! К чему объединяться со Спасителем, если разделяться между собой?» ${ }^{20}$.

Фактически Чаадаев приходит к мысли, четко высказанной уже в XX веке, о том, что Таинство Евхаристии созидает Церковь: Божественный разум живет в людях, а вовсе не в составленной Церковью книге; именно привязанность к «поразительному догмату о действительном присутствии Тела в Евхаристии» достоин уважения, «именно в этом лучше всего постигается источник христианской истины», именно здесь убедительнее всего обнаруживается необходимость стараться всеми средствами «делать действительным присутствие среди нас Богочеловека»:

Этот странный догмат об Евхаристии, предмет издевательства и презрения, открытый со стольких сторон злым нападкам человеческих доводов, сохраняется в некоторых умах, несмотря ни на что, нерушимым и чистым. [...] Не для того ли, чтобы когда-нибудь послужить средством единения между разными христианскими учениями? Не для того ли, чтобы в свое время выявить в мире новый свет, который пока еще скрывается в тайнах судьбы? Я в этом не сомневаюсь ${ }^{21}$.

19 П. Я. Чаадаев, Философические письма, с. 413.

20 П. Я. Чаадаев, Философические письма, с. 413.

21 П. Я. Чаадаев, Философические письма, с. 439. 


\section{2. Роль Церкви и христианства в истории}

Призвание Церкви - дать миру христианскую цивилизацию, а это возможно только «в мощи и силе»; она должна была помочь людям понять, что есть только один способ «познать Бога и поклоняться ему», а это возможно только в случае сохранения единства, именно поэтому западная Церковь избежала и «преувеличенного спиритуализма», и «узкого аскетизма», она «вышла из святилища» и поэтому не «обрекла себя на бесплодие»; «ее земные судьбы могут быть выполнены лишь в условиях человеческого разума, условиях, возлагающих на нее обязанность непрестанно приспособляться к духу времен, через которые ей пришлось проходить, а потому и не следует упрекать ее в том, что она пошла дорогой, предназначенной ей природой вещей, и следовательно единственной, по которой она могла пойти» ${ }^{22}$.

С точки зрения П. Я. Чаадаева, западная Церковь «создана в видах социального развития человечества, [...] вся ее история лишь логическое последствие вложенного в нее организующего начала», а средства, которыми она часто пользовалась и которые на первый взгляд кажутся предосудительными, на самом деле были «единственно возможными. [...] [И] зумительное чутье предназначенной ей роли неизменно руководило ею на протяжении веков борьбы, поражений и поразительных побед» ${ }^{23}$.

Церковь православная - по существу «аскетическая», тогда как католическая по существу «социальная», «отсюда равнодушие одной ко всему, что совершается вне ее, и живое участие другой ко всему на свете. Это - два полюса христианской сферы, вращающейся вокруг оси своей безусловной истины, своей действительной истины. На практике обе церкви часто обмениваются ролями, но

22 Письмо П. Я. Чаадаева к С. С. Мещерской, декабрь 1841 (П. Я. Чаадаев, Письма, op. cit., c. 142).

23 П. Я. Чаадаев, Отрывки и разные мысли, в: П. Я. Чаадаев, Полное собрание сочинений и избранные письма, т. 1, ор. сіt., с. 499-500. 
принципы нельзя оценивать по отдельным явлениям». При этом роль Православия в истории России трудно переоценить: «было преувеличением не воздать должного этой Церкви, столь смиренной, иногда столь героической, которая одна утешает за пустоту наших летописей, которой принадлежит честь каждого мужественного поступка, каждого прекрасного самоотвержения наших отцов, каждой прекрасной страницы нашей истории» ${ }^{24}$.

\section{Общие выводы: два разных способа преодоления религиозного кризиса}

В духовной биографии графа Л. Толстого и П. Я. Чаадаева есть много общего. В первую очередь это преодоление юношеского скептицизма, поиск путей выхода из религиозного кризиса. Влияние эпохи Просвещения в конечном итоге приводит к появлению у того и другого утопических тенденций, главная из которых - идея совершенного человеческого царства, призыв к построению Царства Божьего на земле.

Но, конечно, при этом важно, что на формирование их жизненных позиций оказали влияние совершенно разные авторы. Обращает внимание отсутствие в библиотеке П. Я. Чаадаева писателей, столь значимых для Л. Н. Толстого - А. Шопенгауера и Ж.-Ж. Руссо (интересно, что П. Я. Чаадаеву могли быть вполне доступны все произведения немецкого философа, которые, за одним исключением, впервые были опубликованы еще при жизни П. Я. Чаадаева), а в библиотеке Л. Н. Толстого - авторов-католиков, столь значимых для П. Я. Чаадаева.

Обращает на себя внимание и различие в принятии или отвержении человеческой культуры и истории. С точки зрения Л. Н. Толстого, вера и христианство противопоставлены культуре, а Церковь враждебна прогрессу и является для него главным тормозом; с точки

24 П. Я. Чаадаев, Апология сумасшедшего, в: П. Я. Чаадаев, Полное собрание сочинений и избранные письма, т. 1, ор. сіt., с. 536-537. 
зрения П. Я. Чаадаева, вера, христианство, Церковь - «религиозно обусловленное единство», реальная сила, формирующая и направляющая исторический процесс. При этом сама «церковность» П. Я. Чаадаева носит весьма условный и неопределенный характер, здесь присутствует очевидный сдвиг от сотериологической составляющей к социальности.

И еще одно замечание. Вера Л. Толстого сугубо функциональна, но эта функциональность носит индивидуальный характер она направлении на решение личных вопросов, но никак не связана с проблемой построения культуры. Вера Чаадаева носит более выраженный субстанциональный характер, его очень интересуют догматические категории. В функциональной области, наоборот, он в первую очередь обращает внимание на культурную и социальную программу. Возникает вопрос: эта разница определяется только индивидуальными психологическими характеристиками наших героев, или ее причина более глубока? Ответ на него следует искать уже в будущих исследованиях.

\section{Библиография}

Антонов К. М., П. Я. Чаадаев и творческая программа религиозного западничества (рукопись).

Ильин И. А., Кризис безбожия, Москва 2005.

Тарасов Б. Н., Непрочитанный Чаадаев, неуслышанный Достоевский (христианская мысть и современное сознание), Москва 1999.

Толстой Л. Н., Дневники и записные книжки 1858-1880, в: Л. Н. Толстой, Полное собрание сочинений в 90 томах, т. 48, Москва 1952.

Толстой Л. Н., Письма, 1905 (июль - декабрь) - 1906, в: Л. Н. Толстой, Полное собрание сочинений в 90 томах, т. 76, Москва 1956.

Флоровский Г., Пути русского богословия, http://www.vehi.net/florovsky/puti/06.html. Чаадаев П. Я., Апология сумастедшего, в: П. Я. Чаадаев, Полное собрание сочинений и избранные письма, т. 1, Москва 1991, с. 523-538. 
Чаадаев П. Я., Отрывки и разные мысли, в: П. Я. Чаадаев, Полное собрание сочинений и избранные письма, т. 1, Москва 1991, с. 441-511.

Чаадаев П. Я., Письма, в: П. Я. Чаадаев, Полное собрание сочинений и избранные письма, т. 2, Москва 1991, с. 6-282.

Чаадаев П. Я., Философические письма, в: П. Я. Чаадаев, Полное собрание сочинений и избранные письма, т. 1, Москва 1991, с. 320-440. 